\title{
Use of propofol as an anesthetic and its efficacy on some hematological values of ornamental fish Carassius auratus
}

\author{
Hosna GholipourKanani ${ }^{*}$ and Samaneh Ahadizadeh
}

\begin{abstract}
The aim of this study was to determine the level of anesthesia attained in Carassius auratus using a propofol bath administration and using values of haematological profile of blood and examinations, to assess the effects of the

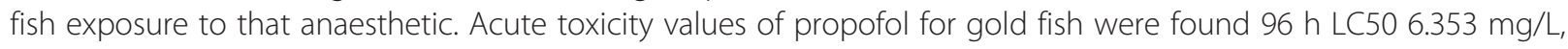
$96 \mathrm{~h} \mathrm{LC1} 2.966 \mathrm{mg} / \mathrm{L}$ and $96 \mathrm{~h} \mathrm{LC99} 13.609 \mathrm{mg} / \mathrm{L}$. Time to induce anesthesia in propofol experiment was significantly higher than Clove oil $(p<0.05)$, but there was no significant difference in recovery time between the experiments. No significant decrease was found in Total RBC, WBC, HCT, MCH, MCV and leukogram indices $(p>0.05)$. MCHC (\%) level of propofol experiment $(13.93 \pm 1.36)$ showed significant $(p<0.05)$ decrease than Clove oil anesthesia (94.95 \pm 24.50$)$ and control $(62.46 \pm 21.90)$. $\mathrm{Hb}(\mathrm{g} / \mathrm{dl})$ content $(5.20 \pm 0.73)$ showed decrease in propofol exposure compared with control $(15.41 \pm 4.76)$ and clove oil experiment $(25.39 \pm 5.73)(p<0.05)$.
\end{abstract}

Keywords: Anesthesia, Gold fish, Hematology, Ornamental, Propofol

\section{Introduction}

In recent years, different types of anesthetics are used to aid in the capture, handling, artificial reproduction, surgery procedures and transport of fish as an anti-stress in modern aquaculture (Roubach et al. 2005).

A few number of anesthetics have proved effective in anaesthetisation of fish with its own advantages and drawbacks (Velíšek et al. 2006). Till now, only MS-222 (tricaine methanesulfonate) is registered for use on food fish in the U.S. and the United Kingdom. However, aquaculture industry needs more compounds to be evaluated experimentally (Coyle et al. 2004) and introduce on ornamental and food fish.

Some anaesthetics reduce or block the activation of the hypothalamic-pituitary-interrenal (HPI) axis associated with stressors and thus decrease or prevent the release of the stress hormone cortisol to the bloodstream of fish (Hoskonen and Pirhonen 2006).

Anesthetics act on the central nervous system in such a way with placing the fish into an anaesthetic solution that is absorbed through the gills and enters the arterial

\footnotetext{
* Correspondence: gholipourk@gmail.com

Department of fisheries and natural resource, agriculture faculty, Gonbad Kavous University, Gonbad Kavous, Iran
}

blood, then with the returning of the anaesthetised fish to the fresh water, the anaesthetics or their metabolites are excreted via the gills (Ross and Ross 1999).

Propofol (2,6 diisopropyl phenol) is an ultra-short-acting sedative agent with no analgesic properties, which provides sedative and anesthetic effects (Kay and Stephenson 1980). Propofol is being widely used as an anaesthetic drug in human patients (Andrews et al., 1997). It is reported to reduce both sympathetic and parasympathetic tone; however, it is not clear whether the changes in heart rate variability are associated with depth of anesthesia. It is generally considered safe for use in animals with renal or hepatic disease also most in instances of mild to moderate heart disease with appropriate monitoring and support.

Propofol is a short-acting, rapidly metabolized agent, which is characterized by a virtual lack of any cumulative effect and by rapid recovery after its administration in bolus doses or by continuous infusion. It provides a reliable, rapid and smooth induction of anaesthesia, adequate hypnosis and analgesia for surgical interventions and minimal suppression of vital organ functions. Moreover, recovery is observed to be rapid, uncomplicated and complete.

Propofol has been used for inducing anesthesia in reptiles such as green iguanas (Knotkova et al. 2005) and 
some fish species such as Acipencer oxyrinchus De soti (Fleming et al. 2003) and in spotted bamboo sharks (Chiloscyllium plagiosum) (Miller et al. 2005), but the efficacy and safety of any anaesthetic agent vary among species, life stages and environmental conditions, and more studies are needed to take advantage of this anesthetic in ornamental fish.

The aim of this study was to compare the effectiveness of propofol to that of the commonly employed clove oil, as an anesthetic for Carassius auratus. Gold fish were exposed to varying doses of propofol to determine the 96-h LC50, as well as exposure to both propofol and eugenol to observe differences in anesthesia onset and recovery times, to determine the proper dosage and to evaluate selected blood parameters during anaesthesia with propofol in gold fish (Carassius auratus).

\section{Method and material}

In the study, propofol (pofol 1\%) manufactured by the Dongkook Pharm Company (Choong cheong Book-Do, Korea) in $50 \mathrm{~mL}$ containers was used. Present research performed with the approval of an appropriate ethics committee INTL K3525.A35 B37 2000.

\section{Experimental fish}

Approximately 207 sexually immature, gold fish were used, with an average weight of $8 \pm 2 \mathrm{~g}$ (mean \pm SD) and a mean fork length of $100 \pm 20 \mathrm{~mm}$. The fish population was distributed equally among ten 50-L holding tanks, each maintained at $22^{\circ} \mathrm{C}$ with well aeration. The fish

Table 2 Induction and recovery times for gold fish anesthetized with 7 ppm propofol and 30 ppm clove oil

\begin{tabular}{ccc}
\hline Time (min) & propofol & Clove oil \\
\hline Anesthesia (Stage 5) & $7.40 \pm .40^{*}$ & $4.26 \pm .60$ \\
Recovery & $8.52 \pm .82$ & $7.95 \pm 1.21$ \\
\hline
\end{tabular}

Results are expressed as the mean $\pm \mathrm{SE} ; \mathrm{N}=36$ for each anesthetic. ${ }^{*} p<0.05$. were maintained on a lighting regimen representative of the local natural environment (13 L: $11 \mathrm{D})$ and fed twice daily to satiation with commercially available flaked tropical fish food. Tanks were siphoned once every second day and approximately $2 \mathrm{~L}$ of water was exchanged during each cleaning.

\section{Acute toxicity of propofol}

Acute toxicity of propofol was ascertained by the OECD 203 "Fish, acute toxicity test" for the 96 h LC50 trials. At first Experimental fish $(n=72)$ were exposed to concentrations $0.5,1,2,4,8$ and $16, \mathrm{mg} / \mathrm{L}$ dissolved in dechlorinated tap water and controls were placed in dechlorinated tap water with no tested substance added in five glass aquaria $(50 \mathrm{~cm} \times 26 \mathrm{~cm} \times 30 \mathrm{~cm})$ filled to a volume of $20 \mathrm{~L}$. Twelve gold fish were randomly used for each concentration and for the control group in 2 replicate. The fish and its behavior, water temperature, $\mathrm{pH}$ and oxygen saturation were monitored throughout the tests at individual concentrations and in the control aquarium. The total mortalities, behaviors, temperature, and oxygen saturation were recorded every hour for the first $12 \mathrm{~h}$ of the experiment, every $3 \mathrm{~h}$ for the next $12 \mathrm{~h}$, and every $6 \mathrm{~h}$ for the remaining $72 \mathrm{~h}$. Fish were considered dead when there were no opercular beats observed for 15 continuously monitored min. This complete experimental protocol was replicated three times.

Mean lethal concentration at $96 \mathrm{~h} \mathrm{LC50} \mathrm{also} 96 \mathrm{~h}$ LC1and 96 h LC99 was calculated from mortality rates over the period of 96 hours by the EPA probit analysis program version 1.5 software.

\section{Onset and recovery from anesthesia}

The observations of stages 5-anesthesia onset were made using propofol and clove oil under the same experimental conditions. A 20- L experimental aquarium was maintained at a temperature of $22^{\circ} \mathrm{C}$ with oxygen saturation greater than $85 \%$. Gold fish $(\mathrm{n}=135)$ were randomly 
Table 3 Effects of propofol and clove oil anaesthesia on haematological indices in gold fish

\begin{tabular}{cccc}
\hline $\begin{array}{c}\text { Indices } \\
\text { Experiments }\end{array}$ & Propofol & Clove oil & Control \\
\hline Erythrocyte $\left(\times 10^{6}\right)$ & $3.20 \pm 0.63 \mathrm{a}$ & $4.33 \pm 0.30 \mathrm{a}$ & $3.43 \pm 0.43 \mathrm{a}$ \\
$\mathrm{Hb}(\mathrm{g} / \mathrm{dL})$ & $5.20 \pm 0.73 \mathrm{a}$ & $25.39 \pm 5.73 \mathrm{~b}$ & $15.41 \pm 4.76 \mathrm{~b}$ \\
$\mathrm{HCT}(\%)$ & $31.80 \pm 2.90 \mathrm{a}$ & $27.40 \pm 1.28 \mathrm{a}$ & $26.60 \pm 2.00 \mathrm{a}$ \\
$\mathrm{MCV}(\mathrm{fl})$ & $137.4 \pm 31.15 \mathrm{a}$ & $64.98 \pm 6.68 \mathrm{a}$ & $83.42 \pm 14.86 \mathrm{a}$ \\
$\mathrm{MCH}(\mathrm{pg})$ & $19.25 \pm 4.34 \mathrm{a}$ & $59.60 \pm 1.43 \mathrm{a}$ & $47.84 \pm 15.14 \mathrm{a}$ \\
$\mathrm{MCHC}(\%)$ & $13.93 \pm 1.36 \mathrm{a}$ & $94.95 \pm 24.50 \mathrm{~b}$ & $62.46 \pm 21.90 \mathrm{~b}$ \\
Leuko $\left(\times 10^{4}\right)$ & $5.60 \pm 0.97 \mathrm{a}$ & $2.37 \pm 0.95 \mathrm{a}$ & $2.97 \pm 0.63 \mathrm{a}$
\end{tabular}

Groups with different alphabetic superscripts differ significantly at $p<0.05$ (ANOVA).

Results are expressed as the mean $\pm \mathrm{SE} ; \mathrm{N}=20$ for each concentration of anesthetic.

distributed into the experimental tank at the treatment concentrations of either $30 \mathrm{ppm}$ clove oil (Valisek et al. 2005) and $7 \mathrm{ppm}$ propofol. Three replicates of 15 fish were used for each anesthetic concentration treatment of propofol, clove oil and control.

The times to achieve stage 5 of anesthesia were also recorded. Once an individual fish had reached the onset of stage 5 anesthesia, a dip net was used to immediately remove it from the tank. The fish was then transferred to a 20-L, well-oxygenated 'recovery' tank (i.e., no anesthesia present) maintained at $22^{\circ} \mathrm{C}$ and observed until it fully recovered. During this recovery period, the fish behavior was observed and times to recovery were recorded.

Once a fish had been used for a treatment, it was left in the recovery aquarium for approximately 1 day prior to being transferred back to a 50-L recovery holding tank for the remainder of a 14-day observational recovery period. Any abnormal behavior or mortalities were recorded during this 14-day recovery period. Anesthesia and recovery stages are presented in Table 1.

\section{Haematological blood profile}

For the haematological blood profile tests, in experimental I twenty of gold fish anesthetized with $7 \mathrm{ppm}$ propofol were examined immediately after $10 \mathrm{~min}$ anaesthesia. In experiment II twenty of gold fish anesthetized with $30 \mathrm{ppm}$ clove oil were examined immediately after $10 \mathrm{~min}$ anaesthesia and in Control group twenty of fish without any anesthesia were hematologicaly tested. Heparinized injection needles were used to take samples of blood from coudal vein of fish. To stabilize blood samples, aqueous solution of heparin sodium salt at $0.01 \mathrm{~mL}$ per $\mathrm{mL}$ of blood was used (Svobodova et al. 1991).

The indices used to evaluate the haematological profile included the erythrocyte count (Er), haemoglobin concentration $(\mathrm{Hb})$, haematocrit $(\mathrm{PCV})$, mean corpuscular volume $(\mathrm{MCV})$, mean corpuscular hemoglobin concentration $(\mathrm{MCHC})$, erythrocyte haemoglobin $(\mathrm{MCH})$, leuko-
Table 4 Effects of propofol and clove oil anaesthesia on differential leukocyte counts in gold fish

\begin{tabular}{|c|c|c|c|}
\hline $\begin{array}{l}\text { Indices (\%) } \\
\text { Experiments }\end{array}$ & Propofol & Clove oil & Control \\
\hline Lymphocytes & $92.80 \pm 0.66 a$ & $92.00 \pm 0.54 a$ & $93.80 \pm 0.37 a$ \\
\hline Monocytes & $0.20 \pm 0.20 a$ & $0.00 \pm 0.00 a$ & $0.00 \pm 0.00 \mathrm{a}$ \\
\hline Neutrophil & $6.60 \pm 0.60 a$ & $7.80 \pm 0.37 a$ & $6.00 \pm 0.44 a$ \\
\hline Eosinophil & $0.40 \pm 0.24 a$ & $0.20 \pm 0.20 \mathrm{a}$ & $0.20 \pm 0.20 a$ \\
\hline
\end{tabular}

cyte count (Leuko) and the differential leukocyte count (Svobodova et al. 1991).

Results of haematological examinations were tested by the variance analysis using the Statgraphics (ANOVATukey Test) software.

\section{Results}

\section{Acute toxicity of propofol}

During the 96-hour LC50 tests, the mean water temperature was $22^{\circ} \mathrm{C}, \mathrm{pH}$ was 7.5 and water oxygen levels were $75-85 \%$ saturation. Based on tests of acute toxicity to gold fish, the 96-hour lethal concentrations of propofol were determined (96 h LC50 $6.353 \mathrm{mg} / \mathrm{L}, 96 \mathrm{~h} \mathrm{LC1}$ $2.966 \mathrm{mg} / \mathrm{L}$ and $96 \mathrm{~h} \mathrm{LC} 9913.609 \mathrm{mg} / \mathrm{L}) .96-\mathrm{h} \mathrm{LC50}$ propofol of gold fish placed into the higher concentration $(16 \mathrm{ppm})$ initially exhibited irritation, as evidenced by rapidly darting about the aquaria, the mortality of this concentration was $100 \%$ after $30 \mathrm{~min}$. The first three concentrations (0.5. 1 and $2 \mathrm{ppm})$ survived the $96 \mathrm{~h}$ trial with $0 \%$ mortality. In concentration of $4 \mathrm{ppm}$ deep sedation was observed after $10 \mathrm{~min}$, with only one mortality after $24 \mathrm{~h}$ of exposure.

\section{Anesthesia and recovery}

The time required to induce anesthesia using propofol $(7 \mathrm{ppm})$ and clove oil $(30 \mathrm{ppm})$ is shown in Table 2.

The time required to induce anesthesia using propofol was significantly higher than Clove oil $(\mathrm{p}<0.05)$, but there was no significant difference in recovery time between the experiments. No mortality in anesthesia group was observed.

\section{Haematological parameters}

Changes in the haematological parameters of gold fish in the control group and those exposed to propofol and clove oil are presented in Tables 3 and 4.

No significant decrease was found in Total RBC, HCT, $\mathrm{WBC}, \mathrm{MCH}, \mathrm{MCV}$ and leukogram indices $(\mathrm{p}>0.05)$. $\mathrm{MCHC}$ level of propofol experiment $(13.93 \pm 1.36)$ showed significant $(\mathrm{p}<0.05)$ decrease than Clove oil experiment $(94.95 \pm 24.50)$ and control $(62.46 \pm 21.90)$. Decrease in 
Hb content $(5.20 \pm 0.73)$ was observed in propofol exposure compared with control $(15.41 \pm 4.76)$ and clove oil experiment $(25.39 \pm 5.73)(\mathrm{p}<0.05)$.

\section{Discussion}

Anaesthetics are necessary for many procedures in aquaculture. The analysis of blood parameters is one of the most valuable methods of anaesthetics evaluation, because it has been shown that the physiological effects of anaesthetics are species-specific and age-dependent (Anver Celik 2004). Because species may differ widely in their response to anaesthetics, screening of their use is necessary.

In this study acute toxicity of propofol to Carassius auratus is investigated from the point of view of propofol use as an anaesthetic, with anaesthetizing baths.

Hematological parameters can provide needed information on the physiological status of fishes, and help the aquaculture and research personnel to make proper decisions to increase the survival of fishes

Propofol (Diprivan ${ }^{\circledR}$, Rapinovet ${ }^{\circledR}$, Propoflo $^{\circledR}$ ), an alkyl phenol hypnotic has been investigated as a widely used intravenous anaesthetic in veterinary practice. Use of propofol as a sole anaesthetic produced effective general anaesthesia in different domestic animals (Duke et al., 1997; Lin et al., 1997; Carroll et al., 1998; Bayan et al., 2002; Zama et al., 2003; 2005) Propofol used as an anaesthetic agent in lizards showed a rapid onset of action. Following intravenous administration in green iguanas, the onset of anaesthesia maybe expected within several minutes (Bennett et al. 1998).

Guénette et al. (2008) determined the level of anesthesia attained in Xenopus laevis frogs using a propofol bath administration. An appropriate anesthetic dose was determined to be $88 \mathrm{mg} / \mathrm{L}$ for $15 \mathrm{~min}$.

There are a few experimental papers reporting the effect of propofol on the fish species. According to FDA guidelines acute toxicity to rainbow trout (Onchorhynchus mykiss) and bluegill sunfish (Lepomis macrochirus) (FDA guideline 4.11, flow-through -no aeration) is $96 \mathrm{~h} \mathrm{LC50=}$ $0.37 \mathrm{mg} / \mathrm{L}$ and $96 \mathrm{~h} \mathrm{LC} 50=0.62 \mathrm{mg} / \mathrm{L}$ respectively. The bio concentration factor (BCF) has been determined for carp, Cyprinus carpio, and the results reported as: (BCF) 28 day $=27($ at $2 \mu \mathrm{g} / \mathrm{L})$ and $(\mathrm{BCF}) 28$ day $=26($ at $0.2 \mu \mathrm{g} / \mathrm{L})$.

The bio degradability of propofol has been assessed according to the OECD guideline $301 \mathrm{~F}$, the results showed $>91 \%$ removal of propofol from the aqueous phase.

Fleming et al. (2003) evaluated propofol for shortterm immobilization of Gulf mexico sturgeon (Acipencer Oxyrinchus de soti) and it was observed that the group receiving intra venous propofol $(6.5 \mathrm{mg} / \mathrm{kg}$ body weight, i.v.) was in a light plane of anesthesia within 5 min after drug administration.
The effect of propofol on haematological parameters is reported in sheep (Brzeski et al., 1994), dogs (Gill et al. 1996), ewes (Handel et al. 1991), rabbits (MazaheriKhameneh et al. 2012) and horses (Mama et al., 1998), no other data on the blood profiles in the fish species anaesthetized with propofol are available in the literature.

Gold fish exposed to propofol showed lower $\mathrm{Hb}$ and $\mathrm{MCHC}$. It is known that propofol induces moderate systemic hypotension, arterial vasodilatation and venodilatation (Branson and Gross, 1994). The lower concentration of $\mathrm{Hb}$, could be explained by haemodynamic changes and re-distribution of blood cellular elements in the vascular bed.

In conclusion, the result of this study indicated that propofol $(7 \mathrm{ppm})$ can induce safe and valid anaesthesia in gold fish. However, it seems that further studies on different dosage, also measuring more haematological and biochemical parameters in the gold fish and other (non-food) ornamental fish following anaesthesia with propofol are needed.

\section{Competing interests}

The authors declare that they have no competing interests.

\section{Authors' contributions}

HG carried out anaesthesia part, and drafted the manuscript. SA participated in the blood parameters assessments. Both authors read and approved the final manuscript.

Received: 29 November 2012 Accepted: 25 February 2013 Published: 4 March 2013

\section{References}

Andrews DT, Leslie K, Sessler DI, Bjorksten AR (1997) The arterial blood propofol concentration preventing movement in $50 \%$ of healthy women after skin incision. Anesth Analg 85:414-419

Anver Celik E (2004) Blood chemistry (electrolytes, lipoprotein and enzymes) values of black scorpion fish (Scorpaena porcus 1758) in the Dardanelles. Turkey J Biol Sci 4:716-719

Bayan H, Sarma KK, Chakravarty P (2002) Biochemical and haematological changes during propofol anaesthesia in canine. Indian J Vet Surg 23:95-96

Bennett RA, Schumacher J, Hedjazi-Haring K, Newlel SM (1998) Cardiopulmonary and anaesthetic effect of propofol administered intraosseously to green iguanas. J Am Vet Med Assoc 212:93-98

Branson KR, Gross ME (1994) Propofol in veterinary medicine. J Am Vet Med Assoc 204:1888-1890

Brzeski W, Depta A, Jalynksi M, Chyczewski M (1994) General anaesthesia in sheep with the use of diprivan-propofol. Med Weter 50:215-217

Carroll GL, Hooper RN, Slater MR, Hartsfield SM, Matthews NS (1998) Detomidinebutorphanol-propofol for carotid artery translocation and castration or ovariectomy in goats. Vet Surg 27:75-82

Coyle SD, Durborow RM, Tidwell JH (2004) Anesthetics in Aquaculture. SRAC Publication No. 3900, Texas, p 6

Duke T, Egger CM, Ferguson JG, Frketic MM (1997) Cardiopulmonary effects of propofol infusion in llamas. Am J Vet Res 58:153-156

Fleming GJ, Heard DJ, Floyd RF, Riggs A (2003) Evaluation of propofol and medetomidine-ketamine for short-term immobilization of Gulf of Mexico sturgeon (Acipenser oxyrinchus de soti). J Zoo Wild Med 34:153-158

Gill JR, Rodriguez JF, Ezquerra LJ, Vives MA, Jimenez J, Uson JM (1996) Development of anaesthesia and changes in the blood parameters in dogs medicated with propofol. Medicina Veterinaria 13:242-246

Guénette SA, Beaudry F, Vachon P (2008) Anesthetic properties of propofol in African clawed frogs (Xenopus laevis). J Am Assoc Lab Anim Sci 47(5):35-38

Handel IG, Staddon GE, Weaver BMQ, Cruz JI (1991) Changes in packed cell volume during anaesthesia. In: Proceedings of the 4th International Congress 
of Veterinary Anaesthesia. J. Vet. Aanesth, Utrecht, Netherlands, pp 25-31, 347-352

Hikasa Y, Takase K, Ogasawara T, Ogasawara S (1986) Anaesthesia and recovery with tricane methanesulphonate, eugenol and thiopental sodium in the carp (Cyprinus carpio). Japanese Journal of Veterinary Science 48:341-351

Hoskonen P, Pirhonen J (2006) The effect of clove oil sedation on oxygen consumption of six temperate-zone fish species. Aquacult Res 35:1002-1005

Jolly DW, Mawdesley-Thomas LE, Bucke D (1972) Anesthesia of fish Vet Rec 91:424-426

Kay B, Stephenson DK (1980) ICI 35868 (Diprivan): A new intravenous anesthetic A comparison with althesin Anaesthesia 35:1182-1187

Keene JL, Noakes DLG, Moccia RD, Soto CG (1998) The efficacy of clove oil as an anaesthetic for rainbow trout, Oncorhynchus mykiss (Walbaum). Aquacult Res 29:89-101

Knotkova Z, Pejrilova S, Trnkova S, Matouskova O, Knotek Z (2005) Influence of reproductive season upon plasma biochemistry values in green iguanas. Acta Veterinaria Brno 74:515-520

Lin HC, Purohit RC, Powe TA (1997) Anaesthesia in sheep with propofol or with xylazine-ketamine followed by halothane. Vet Surg 26:247-252

Mama KR, Steffey EP, Pascoe PJ, Kollias BC (1998) Comparison of two techniques for total intravenous anesthesia in horses. Am J Vet Res 59:1292-1298

Mazaheri-Khameneh R, Sarrafzadeh-Rezaei F, Asri-Rezaei S, Dalir-Naghadeh B (2012) Evaluation of clinical and paraclinical effects of intraosseous vs intravenous administration of propofol on general anesthesia in rabbits. Vet Res Forum 3(2):103-109

McFarland WN (1959) A study of the effects of anesthetics on the behavior and physiology of fishes. Publ Inst Mar Sci Univ Texas 6:337-342

Miller SM, Mitchell MA, Heatley JJ, Wolf T, Lapuz F, Smith JA (2005) Clinical and cardiorespiratory effects of propofol in the spotted bamboo shark (Chiloscyllium plagiosum). J Zoo Wild Anim Med 36:673-676

Ross LG, Ross B (1999) Anaesthetic and Sedative Techniques for Aquatic Animals, 2nd edn. Blackwell Science Ltd., Oxford, p 159

Roubach R, Gomes LC, Fonseca FAL, Val AL (2005) Eugenol as an efficacious anaesthetic for tambaqui, Colossoma macropomum (Cuvier). Aquacult Res 36:1056-1061

Svobodova Z, Pravda D, Palackova J (1991) Unified methods of haematological examination of fish, Methods No. 22nd edn. Res Inst of Fish Cult and Hydrob, Vodnany, p 31

Valisek J, Svobodová Z, Piac4ková V, Groch L, Nepejchalová L (2005) Effects of clove oil anaesthesia on common carp (Cyprinus carpio L.). Vet Med 50 (6):269-275

Velišek J, Wlasow T, Gomulka P, Svobodová Z, Novotný L, Ziomek E (2006) Effects of clove oil anaesthesia on european catfish (Silurus glanis L.). Acta Vet Brno 75:99-106

Zama MMS, Singh NK, Gupta AK, Kumar S, Kalita A (2003) Propofol anaesthesia in adult sheep: Clinical, Haematological and Biochemical studies, 27th Annual Congress of Indian Soc. Vet. Surg. GBPUA \& T. Pantnagar

Zama MMS, Harbans L, Gupta AK, Bhadwal MS (2005) Blood gas and electrolyte changes during propofol anaesthesia in buffalo calves, 29th Annual Congress of Ind. Soc. Vet. Surg. IVRI, Izatnagar, U.P

doi:10.1186/2193-1801-2-76

Cite this article as: GholipourKanani and Ahadizadeh: Use of propofol as an anesthetic and its efficacy on some hematological values of ornamental fish Carassius auratus. SpringerPlus 2013 2:76.

\section{Submit your manuscript to a SpringerOpen ${ }^{\circ}$ journal and benefit from:}

- Convenient online submission

- Rigorous peer review

- Immediate publication on acceptance

- Open access: articles freely available online

- High visibility within the field

- Retaining the copyright to your article

Submit your next manuscript at $\gg$ springeropen.com 